\title{
Risk factors and presence of antibodies to Toxoplasma gondii in dogs from the coast of São Paulo State, Brazil ${ }^{1}$
}

\author{
Rodrigo Costa da Silva ${ }^{2 *}$, Vanessa Yuri de Lima ${ }^{3}$, Erika Maemi Tanaka², \\ Aristeu Vieira da Silva ${ }^{4}$, Luiz Carlos de Souza ${ }^{2}$ and Hélio Langoni ${ }^{2}$
}

\begin{abstract}
Da Silva R.C., Lima V.Y., Tanaka E.M., Da Silva A.V., Souza L.C. \& Langoni H. 2010. Risk factors and presence of antibodies to Toxoplasma gondii in dogs from the coast of São Paulo State, Brazil. Pesquisa Veterinária Brasileira 30(2):161 166. Departamento de Higiene Veterinária e Saúde Pública, Faculdade de Medicina Veterinária e Zootecnia, Universidade Estadual Paulista, Distrito de Rubião Júnior s/n, Botucatu, SP 18618-000, Brazil. E-mail: silva_rcd@yahoo.com.br

Toxoplasmosis is caused by the obligate intracellular protozoan parasite Toxoplasma gondii and affects warm-blooded vertebrates, including pets and man. Dogs are epidemiologically important since they act as sentinels for the infection in humans. The present study aimed to determine the presence of antibodies to $T$. gondii in 205 serum samples from dogs in Ubatuba, Sao Paulo state, Brazil, through indirect immunofluorescence reaction (IFAT), as well as the risk factors related to toxoplasmosis in the animals such as breed, age, sex, access to outdoors, homemade food ingestion, access to untreated water, and contact with rodents. Toxoplasmosis-positive samples accounted for 52/205 $(25.4 \%)$, with titers ranging from 16 to 256 . The serological results presented significant association $(P<0.05)$ with homemade food ingestion (45/118; 38.1\%; Cl95\% $29.9 \%-47.2 \%)$ (OR=7.0; Cl95\% 3.0-16.6), and with access to outdoors where those that do not have access to the street were prevalent $(37 / 121 ; 30.6 \%$; CI95\% $23.1 \%-39.3 \%)(O R=0.5$; $\mathrm{Cl} 95 \%$ 0.2-1.0). These results show that toxoplasmosis in this region is related to problems of sanitary education, mainly concerning the appropriate cooking of foods, since most positive animals did not show significant association with the presence of rodents or untreated water consumption but showed, instead association with ingestion of homemade food. Thus, toxoplasmosis is a public health problem in the studied region, and sanitary measures are needed to control the infection due to the strict relationship between man and dog and the presented risk factors.
\end{abstract}

INDEX TERMS: Toxoplasma gondii, dogs, antibodies, risk factors, infection, public health.

RESUMO.- [Fatores de risco e presença de anticorpos para Toxoplasma gondii em cães do litoral do Estado de São Paulo.] A toxoplasmose é causada por um protozoário parasita intracelular obrigatório, Toxoplasma gondii,

\footnotetext{
${ }^{1}$ Received on August 8, 2009.

Accepted for publication on December 12, 2009.

2 Departamento de Higiene Veterinária e Saúde Pública (DHVSP), Faculdade de Medicina Veterinária e Zootecnia (FMVZ), Universidade Estadual Paulista (Unesp), Campus de Botucatu, Distrito de Rubião Júnior s/n, Botucatu, SP 18618-000, Brazil. "Corresponding author: silva_rcd@yahoo.com.br

${ }^{3}$ Pontifícia Universidade Católica do Paraná (PUC-PR), Campus de Toledo, Avenida da União 500. Jardim Coopagro, Toledo, PR 85903060, Brazil.

${ }^{4}$ Universidade Paranaense (Unipar), Campus de Umuarama. Praça Mascarenhas de Moraes s/n, Centro, Umuarama, PR 87502-210 Brazil.
}

e acomete vertebrados homeotérmicos incluindo animais de companhia e o homem. O cão apresenta importância epidemiológica por atuar como sentinela da infecção para o homem. O presente estudo objetivou determinar a ocorrência de anticorpos para $T$. gondii em 205 amostras de soro de cães do município de Ubatuba, SP, Brasil, pela reação de imunofluorescência indireta (RIFI), assim como os fatores de risco relacionados à infecção nos animais, como raça, idade, sexo, acesso a rua, ingestão de comida caseira, acesso a água não tratada e presença de roedores. 52/205 $(25,4 \%)$ amostras foram positivas para toxoplasmose, com títulos variando de 16 a 256. Os resultados sorológicos apresentaram associação significativa $(P<0,05)$ com consumo de comida caseira $(45 / 118$; 38,1\%; IC95\% 29,9\%-47,2\%) (OR=7,0; Cl95\% 3,0-16,6), 
e acesso a rua, em que aqueles que não tinham acesso a rua foram prevalentes $(37 / 121 ; 30,6 \%$; IC $95 \% 23,1 \%$ $39,3 \%)(\mathrm{OR}=0,5 ; \mathrm{Cl} 95 \%$ 0,2-1,0). Estes resultados demonstram que a toxoplasmose na região está relacionada com problema de educação sanitária, principalmente quanto ao adequado cozimento dos alimentos, visto que a maioria dos animais positivos não apresentou associação significativa com presença de roedores ou consumo de água não tratada, porém os mesmos permaneciam em casa aos quais fora oferecida comida caseira. Portanto, a toxoplasmose consiste em um problema de saúde pública na região estudada, sendo necessárias medidas sanitárias para o controle da infecção, visto a estreita relação homem-cão e os fatores de risco presentes.

TERMOS DE INDEXAÇÃO: Toxoplasma gondii, cães, anticorpos, fatores de risco, infecção, saúde pública.

\section{INTRODUCTION}

Toxoplasmosis is a zoonosis caused by the obligate intracellular parasite protozoan Toxoplasma gondii, which has worldwide distribution and infects most warm-blooded animals, including pets and man (Dubey 1994). The infection prevalence varies with the different species depending on occurrence area, socio-cultural habits, besides weather and geographic factors. Man and animals become infected by ingesting raw or poorly cooked meat containing tissue cysts (Dubey \& Beattie 1988) and by ingesting oocysts present in contaminated feces of cats (definitive hosts) (Frenkel \& Parker 1996, Lindsay et al. 1997, Clementino et al. 2007). Thus, dogs are epidemiologically important since they act as sentinels of the infection to men, mainly errant animals or those with free access to other uncontrolled places preying on birds and rodents (Kawasoe 2000, Brito et al. 2002, Azevedo et al. 2005, Sedlak \& Bartova 2006). Besides, dogs are good indicators of domestic environmental contamination, but in many parts of the world, including Brazil, dogs play a secondary role in $T$. gondii transmission because they are not food source for humans. These animals may be involved in the mechanical transmission of $T$. gondii to humans as reported by others (Frenkel \& Parker 1996, Lindsay et al. 1997), mentioned above in the underlined sentence. The most important fact, however, is that dogs and man are exposed to the same sources of $T$. gondii (Dubey \& Beattie 1988, Cabral et al. 1998, Garcia et al. 1999, Cañón-Franco et al. 2004, Jittapalapong et al. 2007). Thus, this study aimed to determine the frequency of antibodies to Toxoplasma gondii in dogs from Ubatuba, a coastal municipality in São Paulo State, Brazil, characterized by low hygienic-sanitary conditions associated with the tropical conditions of the Brazilian coast and the risk factors that favor the infection in animals.

\section{MATERIALS AND METHODS}

Experimental design and sampling. This study was carried out in Ubatuba, a coastal municipality situated in the north of São Paulo State (23⒉ $6^{\prime}$; $\left.45^{\circ} 04^{\prime} W\right)$, Southeastern region of Brazil, during a technical visit to the municipality, scheduled by the Municipal Secretary of Sanitary Vigilance, Ubatuba Municipal Council. Ubatuba is crossed by the Tropic of Capricorn (INMET 2005) (Fig.1) and presents rainfall index ranging approximately from 1600 to $3000 \mathrm{~mm} / \mathrm{year}$ (PERH 2008); it is located at 250 $\mathrm{km}$ way from the State Capital and is surrounded by "Serra do

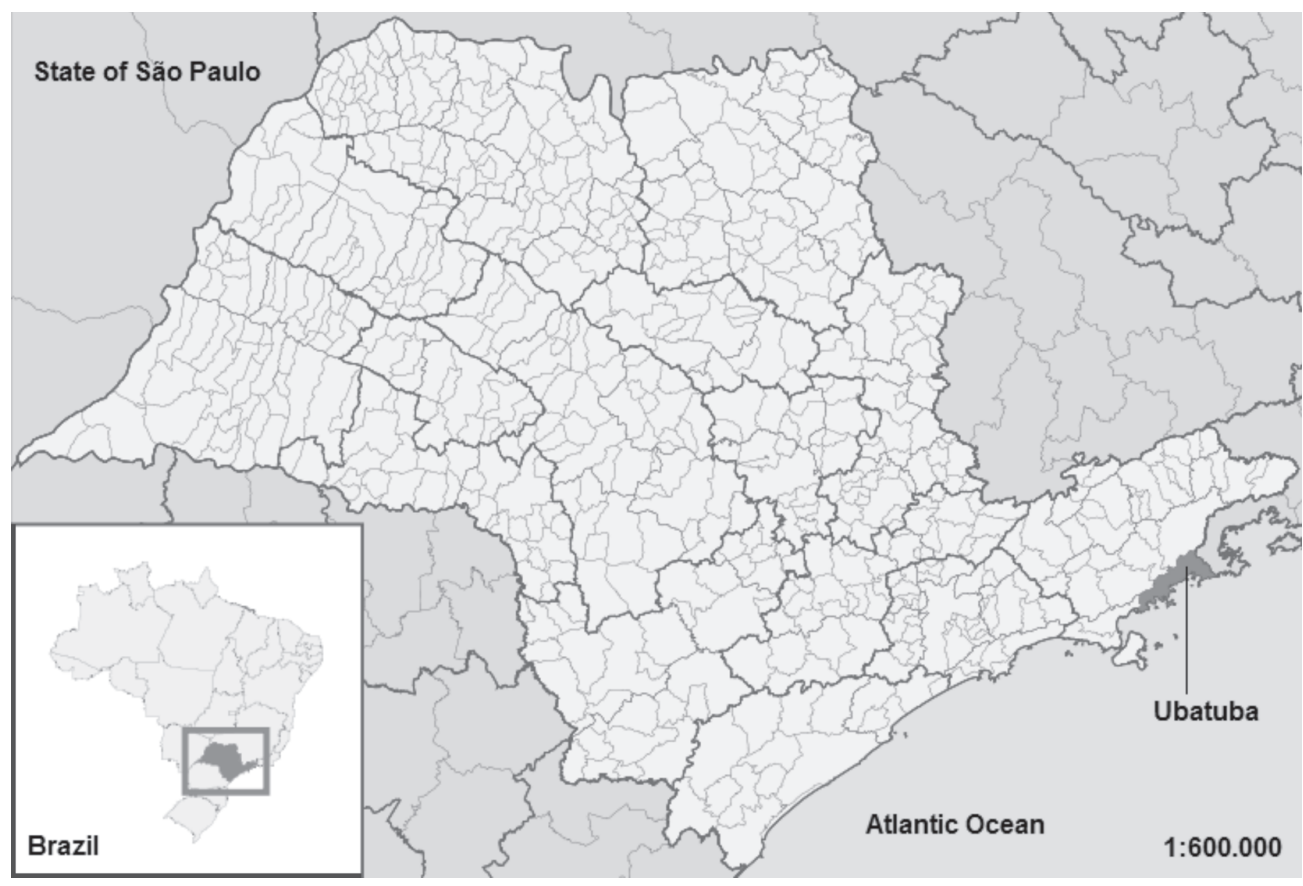

Fig.1. Localization of Ubatuba, São Paulo, Brazil. Adapted from Wikimedia Commons (http:// commons.wikimedia.org). 
Mar" and Atlantic Forest, in a $712 \mathrm{~km}^{2}$ total area and mean altitude of $835 \mathrm{~m}$ above the sea level, but presenting 800 to $1670 \mathrm{~m}$ elevations in its highest parts. The climate is humid tropical, with dominant winds from the south and southeast. Its estimated population is 75,008 inhabitants (IBGE 2008), with demographic density of 105.33 inhabitants $/ \mathrm{km}^{2}$. The urbanization rate is $97.8 \%$, with $22.8 \%$ of the population receiving sanitary treatment and $76.2 \%$ receiving treated water.

This work was conducted as a transversal study, using blood sample collection to detect serum antibodies to Toxoplasma gondii and a questionnaire to survey epidemiological data. The presence of $T$. gondii antibodies was investigated in 205 dogs randomly selected among those from the studied municipality raised in houses and surroundings. Such number was determined based on the human population existent in the municipality and on the calculation of the proportion dog:man, 1:10 (Reichmann et al. 1999), resulting in a population of 7501 dogs. Considering a prevalence of $50 \%$ in the region, the software StatCalc, Epilnfo 3.1, at 95\% confidence level and 7\% error, was used to calculate the number of 191 animals, increased to 205 for safety reasons (Thrusfield 1995). There was no preference for sex, age or breed. All dog owners signed a consent and authorization term for the utilization of samples in this research.

Questionnaire. Before blood sample collection, a comprehensive questionnaire directed to the risk factors of toxoplasmosis was given to the owners or those who raised or fed the dogs used in this study. The questionnaire included information about the dogs' breed, age, sex, homemade food ingestion, access to the street, and access to untreated water (both at home and on the streets), as well as the presence of rodents in the house or surroundings.

Blood collection. Blood samples, 4 to $5 \mathrm{~mL}$, were collected through cephalic or jugular vein puncture. The collected blood was sent to Nupezo (Zoonosis Research Center) at the Department of Veterinary Hygiene and Public Health, São Paulo State University (Unesp), Botucatu, SP, Brazil, where it was centrifuged at $1,600 \times g$ for 10 minutes. Then, the serum was transferred to microtubes and stored at $-20^{\circ} \mathrm{C}$.
Indirect immunofluorescence reaction (IFAT). Serum samples were investigated for the presence of antibodies to Toxoplasma gondii through indirect immunofluorescence reaction (IFAT), using the dilutions 1:16, 1:64, 1:256, 1:1024 and 1:4096, according to Camargo (1974). The used anti-dog IgG antibody, conjugated to fluorescein isothiocyanate, was kindly supplied by the Centro de Controle de Zoonoses in São Paulo (CCZ-SP) and diluted at 1:300 in Evans Blue solution $20 \mathrm{mg} \%$. Readings were done in a microscope "Zeiss SH250"; the sera reacting in the dilution 1:16 were considered positive (Silva et al. 1997).

Statistical analysis. The contribution of the studied epidemiological variables to the result of the serological test to toxoplasmosis was verified through Chi-square or Fischer's Exact test using InStat 3 software, with $\alpha=0.05$.

\section{RESULTS}

Indirect immunofluorescence results indicated 25.4\% (52/ 205) positivity, with higher frequency in dogs from de coast of São Paulo State. The predominant titers were 16 in 8/ 52 samples (15.4\%; Cl95\% 8.1-27.6\%), 64 in 29/52 samples (55.8\%; Cl95\% 42.3-68.4\%), and 256 in 15/52 samples (28.8\%; Cl95\% 18.3-42.4\%).

As shown in Table 1, there was no significant association between serological results and sex, age, access to untreated water or presence of rodents (P>0.05). On the other hand, serology was associated with non-access to the street (30.6\%; CI95\% 23.1-39.3\%; OR=0.5; IC95\% 0.2$1.0)$ and homemade food ingestion (38.1\%; CI95\% 29.947.2\%; OR=7.0; IC95\% 3.0-16.6).

\section{DISCUSSION}

In the present study, $25.4 \%$ of the tested samples were positive by IFAT and were within the State range from 19.7 to $33.1 \%$ (Brito et al. 2002, Souza et al. 2003, Langoni et al. 2006) and the national range from 8.2 to $88.5 \%$ (Silva et al.

Table 1. Epidemiological results obtained with the questionnaire applied to the dog owners and the association with the serological results for toxoplasmosis in dogs from Ubatuba, São Paulo, Brazil

\begin{tabular}{|c|c|c|c|c|c|c|}
\hline \multirow{2}{*}{$\begin{array}{l}\text { Variables } \\
\text { Sex }\end{array}$} & \multicolumn{2}{|c|}{$\mathrm{N}$} & \multirow{2}{*}{$\frac{\text { IFAT }^{\mathrm{a}}}{25}$} & \multirow{2}{*}{$\begin{array}{c}\begin{array}{c}\text { Positive dogs (\%); } \\
\text { Cl95\% }\end{array} \\
26.3 ; 18.5-36.0\end{array}$} & \multirow{2}{*}{$\begin{array}{c}\text { OR; } \mathrm{Cl} 95 \% \mathrm{c} \\
1.1 ; 0.6-2.1\end{array}$} & \multirow{2}{*}{$\begin{array}{c}P^{\mathrm{d}} \\
0.45\end{array}$} \\
\hline & Male & 95 & & & & \\
\hline & Female & 110 & 27 & $24.5 ; 17.5-33.4$ & & \\
\hline \multirow[t]{2}{*}{ Breed } & DEFe & 34 & 12 & $35.3 ; 21.5-52.2$ & $1.8 ; 0.8-3.9$ & 0.11 \\
\hline & UDF $^{f}$ & 171 & 40 & $23.4 ; 17.7-30.3$ & & \\
\hline \multirow[t]{3}{*}{ Age (years-old) } & $0.0-4,0$ & 80 & 26 & $32.5 ; 23.2-43.4$ & - & 0.16 \\
\hline & 4.1-8.0 & 73 & 16 & $21.9 ; 14.0-32.7$ & & \\
\hline & $8.1-12.0$ & 52 & 10 & $19.2 ; 10.8-32.0$ & & \\
\hline \multirow[t]{2}{*}{ Homemade food ingestion } & Yes & 118 & 45 & $38.1 ; 29.9-47.2$ & $7.0 ; 3.0-16.6$ & $<0.0001$ \\
\hline & No & 87 & 7 & $8.0 ; \quad 4.0-15.7$ & & \\
\hline \multirow[t]{2}{*}{ Access to the street } & Yes & 84 & 15 & $17.9 ; 11.2-27.4$ & $0.5 ; 0.2-1.0$ & 0.02 \\
\hline & No & 121 & 37 & $30.6 ; 23.1-39.3$ & & \\
\hline \multirow[t]{2}{*}{ Access to untreated water } & Yes & 77 & 24 & $31.2 ; 21.9-42.2$ & $1.6 ; 0.8-3.1$ & 0.09 \\
\hline & No & 128 & 28 & $21.9 ; 15.6-29.8$ & & \\
\hline \multirow[t]{2}{*}{ Presence of rodents } & Yes & 80 & 22 & $27.5 ; 18.9-38.2$ & $1.2 ; 0.6-2.8$ & 0.34 \\
\hline & No & 125 & 30 & $24.0 ; 17.4-32.2$ & & \\
\hline
\end{tabular}

a Titer $\geq 16$; ${ }^{b}$ Frequency of positive animals based on the studied variable (confidence interval $=95 \%$ ); ${ }^{c}$ Odds ratio; ${ }^{d} P$ value to $\alpha=5$; e Defined breed; ${ }^{f}$ Undefined breed. 
1997, Souza et al. 2003, Cañón-Franco et al. 2004, Azevedo et al. 2005, Romanelli et al. 2007, Figueredo et al. 2008, Da Silva et al. 2009, Santos et al. 2009). Such variation is mainly due to the large territorial extension of Brazil, with wide diversity of cultures, behaviors, socioeconomic and hygienic-sanitary conditions, besides the parasite intrinsic aspects like genetic variability. However, the disease worldwide prevalence in dogs is not too different from this range due to the same factors and is also frequently associated with religious conditions (Acha \& Szyfres 2003). An example of this situation is observed in European, Asian and South-American continents. Sedlak \& Bartova (2006) reported 107/413 (25.9\%) prevalence in Czech Republic, and Wanha et al. (2005), 84/242 (35\%) in Austria, whereas in Asian, Öncel et al. (2007) observed $77 / 150$ (51.3\%) in Turkey; Dubey et al. (2007b), 21/42 (50\%) in Vietnam; Dubey et al. (2007c), 58/86 (67.4\%) in Sri Lanka; and Tsai et al. (2008) 284/1412 (20.1\%) in Taiwan. In South America, except Brazil, the wide diversity of which was already reported, Dubey et al. (2007a) detected 52/309 (16.8\%) seropositive dogs in Colombia.

Animals with titers 64 (29/52; 55.8\%; Cl95\% 42.3$68.4 \%)$ predominated over those with titers $16(8 / 52$; 15.4\%; CI95 8.1-27.6\%) and 256 (15/52; 28.8\%; Cl95\% 18.3-42.4\%). Generally, infected dogs kept asymptomatic but with low antibody levels. Several studies have determined more than $50 \%$ animals reacting to titers below 256 (Silva et al. 1997, Brito et al. 2002, Azevedo et al. 2005, Langoni et al. 2006, Dubey et al. 2007b,c, Öncel et al. 2007, Romanelli et al. 2007, Da Silva et al. 2009, Santos et al. 2009). On the other hand, Cañón-Franco et al. (2004) observed that most of the $76.4 \%$ seropositive dogs did not have low titers, ranging from 128 to 2048, which may indicate active infection. To avoid misinterpretation of the infection profile in the studied region, seroepidemiological surveys should be more explored as to low titers, or different serological tests should be combined since serologies done at one single moment may hide an active infection (Silva et al. 1997).

Dogs are intermediate hosts of Toxoplasma gondii infection and do not eliminate oocysts in their feces, as the sexual phase of the parasite cycle does not occur in this stage. However, some studies have reported that dogs can mechanically transmit oocysts through the feces to men (Frenkel \& Parker 1996, Lindsay et al. 1997, Clementino et al. 2007). On the other hand, dogs epidemiologically act as perfect sentinels of $T$. gondii infection to men, allowing the evaluation of the rate of environmental contamination with oocysts in both urban and rural areas, as well by ingestion of raw or undercooked meat with tissue cysts (Souza et al. 2003, Azevedo et al. 2005, Langoni et al. 2006, Santos et al. 2009). Santos et al. (2009) demonstrated such relationship by identifying 54/61 (88.5\%) dogs and 113/116 (97.4\%) men serologically positive to T. gondii in 50 farms studied in Mato Grosso State, Brazil. Certainly, cats present a fundamental importance in environmental contamination but the role of dogs as sentinels in this study show their importance to study toxoplasmosis epidemiology. Ortolani et al. (2005) also verified high prevalence $(88.2 \%)$ in dogs from an Indian village in Brazil.

Analyzing risk factors, significant associations can be observed concerning the variables "homemade food ingestion" (38.14\%; CI95\% 29.87-47.16\%) and "access to the street" $(30.6 \%$; Cl95\% 23.1-39.3\%) $(P<0.05)$, the latter being considered a protective factor, since nonaccess to the street favored the occurrence of infection, with odds ratio $(\mathrm{OR})=0.5(\mathrm{Cl} 195 \% 0.2-1.0)$. Even if the owner reported in the questionnaire that the dog has no access to the street, cats may have free access to the gardens and yards of the house, promoting therefore the site contamination. Thus, dogs might have been infected in their own house or surroundings, as observed by CañónFranco et al. (2004), who detected $84.9 \%$ positive dogs having access to the street and $58.8 \%$ ones raised in the house. However, this result may also be related to "homemade food ingestion", OR=7.0 (Cl95\% 3.0-16.6), which is only a suggestion since this variable was not explored concerning the type of food and the way it was prepared; besides, the animals might have been infected by oocysts in water contaminated with feces of cats or by ingesting tissue cysts present in raw meat of unsafe origin (Dubey \& Beattie 1988, Souza et al. 2003, Langoni et al. 2006). Such variable is a very important item in Brazil since most of the population is used to feeding dogs on leftovers, which are generally raw or poorly cooked food of unsafe origin. In addition, there are precarious sanitary conditions, including scarce technical knowledge about infections important to public health and raising of pets (dogs and cats), as well as production animals in the house and surroundings, concomitantly (Santos et al. 2009). The presence of cats, when studied, generally shows a significant association, as observed by Azevedo et al. (2005). This indicates that presence of and/or strict contact with cats constitutes important factors to be considered in the infection epidemiology. Felids are the pivots in the transmission of $T$. gondii to humans and other animals since only these hosts eliminate environment-resistant oocysts in the feces (Dubey \& Beattie 1988, Romanelli et al. 2007, Soares et al. 2009).

Generally, younger animals are more predisposed to the infection due to low immunity and exploratory habits, characteristic of hunting animals such as dogs, associated with the playful habits of pups. In this study, although there was higher occurrence among 0-4.1-year-old animals (32.5\%; CI95\% 23.2-43.4\%), followed by the intermediate age range (21.9; Cl95\% 14.0-32.7\%), no significant association was detected in the analysis of either all three age ranges or each two ranges; differently from Langoni et al. (2006), who observed higher occurrence among the oldest animals, $13.3-20$ years (75\%), and Da Silva et al. (2009), who reported higher frequencies in age ranges above $6-8$ years.

The presence of rodents was only reported by $27.5 \%$ 
(Cl95\% 18.9-38.2\%) of the owners, with no significant difference ( $P>0.05)$, as well as the access to untreated water prevailed in this study (31.2\%; Cl95\% 21.9-42.2\%); however, it is an important factor to be considered since the presence of rats may lead to the presence of cats, their natural predators. Errand cats tend to have higher predatory instinct in the search for food, justifying their access into the house. On the other hand, the response to the questionnaire may be masked, since a rodent has nocturnal habits and might have not been seen although present in the house, attracting cats. Differently, Romanelli et al. (2007) verified that the presence of rodents in food storage places was an important factor in a study with sheep and dogs; in such places, rodents may serve as sources of infection to dogs.

Factors such as sex and breed did not show significant association $(P>0.05)$ although there was higher occurrence among males (26.3\%; CI95\% 18.5-36.0\%). The same was observed by Öncel et al. (2007) in dogs of defined breed (35.3\%; CI95\% 21.5-52.2\%). Langoni et al. (2006) verified that $35.9 \%$ of the reagents had non-defined breed, which is justifiable as they have predatory habits, whereas Brito et al. (2002) noticed that $48.7 \%$ reagents were $\leq 1$ year old. Titer distribution was uniform concerning sex, untreated water and homemade food ingestion.

Studying the epidemiological factors are very important to understand how the infection behaviors in each studied area; however, attention should also be given to the parasite intrinsic factors, mainly those related to genetic variability, which may affect the varied worldwide prevalence already reported. Thus, Dubey et al. (2007b) identified that the variability among $T$. gondii genotypes may interfere with the infection and/or disease occurrence, in which certain isolates of the parasite may present evolutive mutations and consequently be phenotypically more aggressive or not.

\section{CONCLUSIONS}

The evaluation of serological results and their association with the analyzed epidemiological variables indicate that Toxoplasma gondii infection occurs in dogs from Ubatuba Municipality, São Paulo State, Brazil, at a considerable percentage. This is associated with home condition and homemade food ingestion, that can include raw and undercooked meat which can be a risk factor to the dog and human population, especially immuno-compromised individuals and pregnant women, who are exposed to the same infection sources and routes. Thus, cooking the meat and more hygienic care as to gardening habits and contact with the soil and feces of cats before food ingestion are necessary to avoid the infection.

Acknowledgements.- To the students of the Discipline Epidemiology and Sanitation, Graduate Program in Veterinary Medicine, School of Veterinary Medicine and Animal Science, São Paulo State University (Unesp), who helped in blood sample collections. We are also grateful to Ubatuba Municipal Council and Unesp for logistic support.

\section{REFERENCES}

Acha P. \& Szyfres B. 2003. Zoonosis y enfermedades transmisibles communes al hombre y a los animals. $3^{\mathrm{a}}$ ed. Organización Panamericana de la Salud. Publicación Científica. 413p.

Azevedo S.S., Batista C.S.A., Vasconcellos S.A., Aguiar D.M., Ragozo A.M.A., Rodrigues A.A.R., Alves C.J. \& Gennari S.M. 2005. Seroepidemiology of Toxoplasma gondii and Neospora caninum in dogs from the state of Paraíba, Northeast region of Brazil. Res. Vet. Sci. 79:51-56.

Brito A.F., De Souza L.C., Da Silva A.V. \& Langoni H. 2002. Epidemiological and serological aspects in canine toxoplasmosis in animals with nervous symptoms. Mem. Inst. Oswaldo Cruz 97:31-35.

Cabral D.D., Silva D.A.O., Mineo J.R., Ferreira F.A. \& Duran F.P. 1998. Frequency of anti-Toxoplasma gondii antibodies in apparently healthy dogs of the city of Uberlandia-MG. Braz. J. Vet. Parasitol. 7:87-90.

Camargo M.E. 1974. Introdução às técnicas de imunofluorescência. Rev. Bras. Patol. Clin. 10:143-169.

Cañón-Franco W.A., Bargamaschi D.P., Labruna M.B., Camargo L.M.A., Silva J.C.R., Pinter A. \& Gennari S.M. 2004. Occurrence of anti-Toxoplasma gondii antibodies in dogs in the urban area of Monte Negro, Rondônia, Brazil. Vet. Res. Commun. 28:113-118.

Clementino M.M., Souza M.F. \& Andrade Neto V.F. 2007. Soroprevalence and Toxoplasma gondii-IgG avidity in sheep from Lajes, Brasil. Vet. Parasitol. 146:199-203.

Da Silva A.V., Gonçalves G.F., Lívero F.A.R., Bottin J.M.P., Belinato F.C., Bastos Júnior E.A., Da Silva R.C. \& Langoni H. 2009. Avaliação de fatores epidemiológicos na ocorrência de anticorpos contra Toxoplasma gondii em cães atendidos em um Hospital Universitário. Vet. Zootec. 16:239-247.

Dubey J.P. \& Beattie C.P. 1988. Toxoplasmosis of Animals and Man. CRC Press, Boca Raton, p. 220.

Dubey J.P. 1994. Toxoplasmosis. J. Am. Vet. Med. Assoc. 205:15931598.

Dubey J.P., Cortés-Vecino J.A., Vargas-Duarte J.J., Sundar N., Velmurugan G.V., Bandini L.M., Polo L.J., Zambrano L., Mora L.E., Kwok O.C.H., Smith T. \& Su C. 2007a. Prevalence of Toxoplasma gondii in dogs from Colombia, South America and genetic characterization of T. gondii isolates. Vet. Parasitol. 145:45-50.

Dubey J.P., Huong L.T.T., Sundar N. \& Su C. 2007b. Genetic characterization of Toxoplasma gondii isolates in dogs from Vietnam suggests their South American origin. Vet. Parasitol. 146:347-351.

Dubey J.P., Rajapakse R.P.V.J., Wijesundera R.R.M.K.K., Sundar N., Velmurugan G.V., Kwok O.C.H. \& Su C. 2007c. Prevalence of Toxoplasma gondii in dogs from Sri Lanka and genetic characterization of the parasite isolates. Vet. Parasitol. 146:341-346.

Figueredo L.A., Dantas-Torres F., Faria E.B., Pita Gondim L.F., SimõesMattos L., Brandão-Filho S.P. \& Mota R.A. 2008. Occurrence of antibodies to Neospora caninum and Toxoplasma gondii in dogs from Pernambuco, Northeast Brazil. Vet. Parasitol. 157:9-13.

Frenkel J.K. \& Parker B.B. 1996. An apparent role of dogs in the transmission of Toxoplasma gondii: the probable importance of xenosmophilia. Ann. N. Y. Acad. Sci. 791:402-407.

Garcia J.L., Navarro I.T., Ogawa L. \& Oliveira R.C. 1999. Soroprevalência do Toxoplasma gondii em suínos, bovinos, ovinos e equinos, e sua correlação com humanos, felinos e caninos, oriundos de propriedades rurais do norte do Paraná, Brasil. Ciência Rural 29:91-97.

IBGE 2008. Cidades. Instituto Brasileiro de Geografia e Estatística. 2007. Disponível em: <http://www.ibge.gov.br/cidadesat/topwindow.htm?1>. Acesso em 5 de setembro de 2008.

INMET 2005. Instituto Nacional de Meteorologia 7. Distrito de Meteorologia (7. DISME). Estação de Ubatuba-SP, Relatório sobre variação média mensal de temperatura e pluviometria entre 1994 e 2003, no município de Ubatuba. 
Jittapalapong S., Nimsupan B., Pinyopanuwat N., Chimnoi W., Kabeya H. \& Maruyama S. 2007. Seroprevalence of Toxoplasma gondii antibodies in stray cats and dogs in the Bangkok metropolitan area, Thailand. Vet. Parasitol. 145:138-141.

Kawasoe U. 2000. Toxoplasma gondii, p.147-156. In: Neves D.P., Melo A.L., Genaro O. \& Linardi P.M. (Eds), Parasitologia Humana. 10ª ed. Atheneu, São Paulo.

Langoni H., Modolo J.R., Pezerico S.B., Silva R.C., Castro A.P.B., Da Silva A.V. \& Padovani C.R. 2006. Serological profile of anti-Toxoplasma gondii antibodies in apparently healthy dogs of the city of Botucatu, São Paulo State, Brazil. J. Venom. Anim. Toxins incl. Trop. Dis. 12: $42-148$

Lindsay D.S., Dubey J.P., Butler J.M. \& Blagburn B.L. 1997. Mechanical transmission of Toxoplasma gondii oocysts by dogs. Vet. Parasitol. 73:27-33

Öncel T., Handemir E., Kamburgil K. \& Yurtalan S. 2007. Determination of seropositivity for Toxoplasma gondii in stray dogs in Istanbul, Turkey. Rev. Med. Vet. 158:223-228.

Ortolani E.S., Gennari S.M., Pinheiro S.R., Rodrigues A.A.R., Chibao D.P. \& Soares R.M. 2005. Prevalência de anticorpos anti-Toxoplasma gondii em populações animais das aldeias indígenas krucutu e Morro da Saudade, no município de São Paulo. Brasil. Vet. Zootec. 12:25-28.

PERH. 2008. Programa Estadual dos Recursos Hídricos 2004-2007. Governo do Estado de São Paulo. UGRHI 03 Litoral Norte. Disponível em: <http://www.comitepcj.sp.gov.br/download/PERH/0407_UGRHI-03.pdf>. Acesso em 29 de janeiro de 2008.

Reichmann M.L.A.B., Pinto H.B.F. \& Nunes V.F.P. 1999. Vacinação contra a raiva de cães e gatos. Manuais 3 , Instituto Pasteur, São Paulo, p.32.

Romanelli P.R., Freire R.L., Vidotto O., Marana E.R.M., Ogawa L., De
Paula V.S.O., Garcia J.L. \& Navarro I.T. 2007. Prevalence of Neospora caninum and Toxoplasma gondii in sheep and dogs from Guarapuava farms, Paraná State, Brazil. Res. Vet. Sci. 82:202-207.

Santos T.R., Costa A.J., Toniollo G.H., Luvizotto M.C.R., Benetti A.H., Santos R.R., Matta D.H., Lopes W.D.Z., Oliveira J.A. \& Oliveira G.P. 2009. Prevalence of anti-Toxoplasma gondii antibodies in dairy cattle, dogs, and humans from the Jauru micro-region, Mato Grosso state, Brazil. Vet. Parasitol. 161:324-326.

Sedlak K. \& Bartova E. 2006. The prevalence of Toxoplasma gondii IgM and IgG antibodies in dogs and cats from the Czech Republic. Vet. Med. 51:555-558.

Silva D.A.O., Cabral D.D., Bernardina B.L.D., Souza M.A. \& Mineo J.R. 1997. Detection of Toxoplasma gondii-specific antibodies in dogs. A comparative study of immunoenzymatic, immunofluorescent and haemagglutination titers. Mem. Inst. Oswaldo Cruz 92:785-789.

Soares H.S., Ahid S.M.M., Bezerra A.C.D.S., Pena H.F.J., Dias R.A. \& Gennari S.M. 2009. Prevalence of anti-Toxoplasma gondii and antiNeospora caninum antibodies in sheep from Mossoró, Rio Grande do Norte, Brazil. Vet. Parasitol. 160:211-214.

Souza S.L.P., Gennari S.M., Yai L.E.O., D'auria S.R.N., Cardoso S.M.S., Guimarães Júnior J.S. \& Dubey J.P. 2003. Occurrence of Toxoplasma gondii antibodies in sera from dogs of the urban and rural areas from Brazil. Braz. J. Vet. Parasitol. 12:1-3.

Thrusfield M. 1995. Veterinary Epidemiology. $2^{\mathrm{a}}$ ed. University Press, Blackwell Science, Cambridge, p.479.

Tsai Y.-J., Chung W.-C., Fei A.C.Y., Hong C.-L., Tsai Y.-Y., Peng S. \& Wu Y.-L. 2008. Prevalence of Toxoplasma gondii antibodies in stray dogs in Taipei, Taiwan. J. Parasitol. 94:1437.

Wanha K., Edelhofer R., Gabler-Eduardo C. \& Prosl H. 2005. Prevalence of antibodies against Neospora caninum and Toxoplasma gondii in dogs and foxes in Austria. Vet. Parasitol. 128:189-193. 